\title{
GUSTAV NYLIN
}

Professor Nylin, Honorary President of the European Society of Cardiology and Honorary Member of the British Cardiac Society, died in Stockholm in the great Sodersjukhuset that he had helped to plan, on August 6th at the age of sixty-eight. In his passing cardiology has suffered the loss of an inspired worker and an outstanding personality.

Karl Gustav Nylin was born in December 1892 and graduated in medicine at Stockholm. He was interested in pediatrics and physiology as a young man. Working in the Seraphimer Hospital and the Carolinska Institute, he made comprehensive studies of the development of children and combined this with determinations of the minute volume of the heart using Grollman's acetylene method. Seeking further means of studying the circulation, Nylin went in May 1939 to Copenhagen where he first met Hevesy. It was at this time that the technique of tagging red cells with radio-active phosphorus was introduced and Nylin at once recognised the potentialities this offered for the study of the circulation in cardiovascular disease. So began his life's work which he pursued during twentytwo years.

Before these investigations could begin, the war intervened and during these years Nylin was head of the Sabbatsberg Hospital. He had at this time collaborated with Crafoord in the study of coarctation of the aorta; their paper (J. Thor. Surg., 1945, 14, 347) described the surgical means of correcting this anomaly, an operation that was soon to become securely established and brought relief to sufferers the world over.

The works for which Nylin is best known are those for which he employed isotopes to investigate the distribution of blood in the body. Labelling red cells with radio-active phosphorus, and later with thorium, he carried out a brilliant series of researches on blood volume in health (Brit. Heart J., $1945,7,81)$. This method was analagous to the decholin method for the investigation of circulation time which Nylin had employed in earlier work, and by means of it he put previous observations on a quantitative basis. A comparison of dilution curves between normal hearts and failing hearts, and later detailed analyses of the concentration curves as a function of time, led to calculations of the residual blood in the heart and lungs (Amer. Heart J., 1955, 49, 803); thence he showed that there was a correlation between the heart volume as estimated by roentgenology and the amount of blood in the heart and lungs. Subsequent studies by this method included the influence of strenuous work on the circulation, the effects of posture on blood distribution and the results of closure of a patent ductus arteriosus on the number of circulating red cells.

During the past six years Nylin turned his attention to the cerebral circulation, estimating the flow by injecting thorium B tagged red cells into the carotid artery and recovering blood from both jugular bulbs, the activity of the serial samples being estimated (Brit. Heart J., 1956, 18, 385). For ingenuity of method, logical development and pertinacity, these works stand high in the annals of cardiovascular investigation.

For all his dedication to work and research, Nylin was a sociable and warm-hearted man with a flair for organization. It was in his mind that the concept of the European Society of Cardiology first took shape; the meeting in Brussels in 1949 with Laubry, Parkinson and Rylant marked the genesis of this Society. To its organization he devoted a great deal of time and energy. As its President in 1952 he played an important part in the First Congress of the Society which was held in London under the Chairmanship of Sir John Parkinson. He gave a charming address on the history of cardiology, emphasizing particularly the part played by British physicians and physiologists. This was the year in which Nylin reached his sixtieth birthday and to mark the occasion, an issue of Cardiologia, 


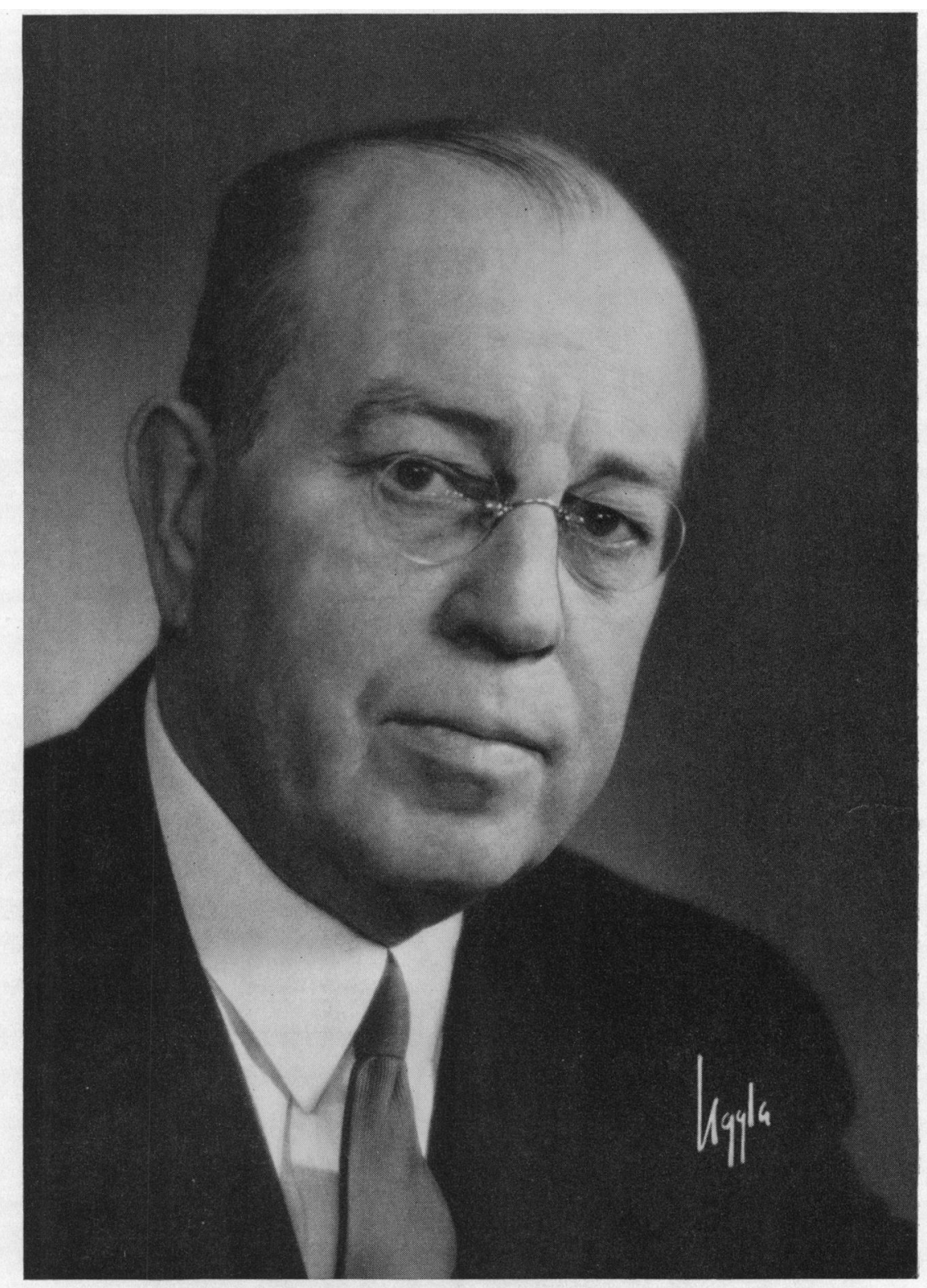

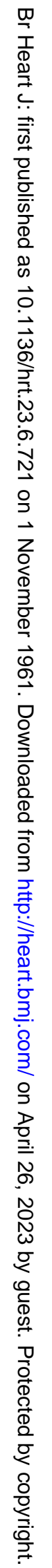


comprising papers by his friends and associates, was dedicated to him. The British Cardiac Society elected him an Honorary Member in 1954 and three years later he was accorded a distinction that he prized perhaps above all others, the Fellowship of the Royal College of Physicians of London. In the following year, Nylin had the high satisfaction of welcoming a host of European Cardiologists and quite a few from America when they assembled in Stockholm for the Second European Congress, in September 1956.

Nylin was a spirited and indefatigable traveller. With Madam Nylin he visited numerous centres in Europe and across the Atlantic, where he received many honorary doctorates and decorations. He was not only an accepted authority and a recognized leader of cardiovascular research but also a cherished guest in the homes of the famous. In his journeys across the world, England, and especially London, was a magnet that attracted him and usually succeeded in bringing him to rest for a few days among friends to whom his presence and that of his gracious wife was invariably a delight. Modest though not self-effacing, he would say that he had come from, say, Vancouver, but the fact that he had just been accorded a special distinction or that he had been invited to address a distinguished gathering, took some time to discover. In his last address as Honorary President of the Third European Congress in Rome a year ago. Nylin stated simply his outlook on modern cardiology. "Many postulate that the doctor today has lost the close contact with the patient and forgotten the noble inheritance from skilful generations of doctors who, with simple but deeply penetrating observations of symptoms both from the physical and psychological point of view, performed their tasks as an art. Today we need a combination of scientist and physician." Of Nylin it may truly be said that he excelled as both.

Professor Nylin published, between 1926 and 1961, upwards of 150 papers, personally or in collaboration. The following 31 publications have been selected as representative of his main interests, as the most important of the works with special regard to those produced in England and America and those published in English.

K. SHIRLEY SMITH

\section{Publications}

Growth and standard metabolism in children of elementary schools during different periods of the year. Verhandlungen des Vierzehnten Nordischen Kongresses due Innere Medizin. Helsingfors, 1930, 356.

The cardiac output of children. Skand. Arch. Physiol., 66, 97, 1933.

The relations between heart volume and stroke volume in recumbent and erect positions. Skand. Arch. Physiol., 69, 237, 1934.

(With E. Lysholm and K. Quarna.) The relation between the heart volume and stroke volume under physiological conditions. Acta radiol., Stockh., 15, 237, 1934.

(With G. Liljestrand and E. Lysholm.) The immediate effects of muscular work on the stroke and heart volume in man.

Skand. Arch. Physiol., 80, 265, 1938.

(With G. Liljestrand and C. G. Zachrisson.) The normal heart volume in man. Amer. Heart J., 17, 406, 1939.

William Withering-bicentenary tribute. Amer. Heart J., 25, 285, 1943

On the amount of, and changes in the residual blood of the heart. Amer. Heart J., 25, 598, 1943.

Digitalis-und Stropantustherapie. Cardiologia, 7, 281, 1943.

(With Mignon Malm.) Uber die Konzentration von mit radioaktivem Phosphor markierten Erythrocyten im Arterienblut der intravenosen Injektion solcher Blutkorperchen. Cardiologia, 7, 153, 1943.

The dilution curve of activity in arterial blood after the injection of labelled corpuscles. Amer. Heart J., 30, 1, 1945. 
Blood volume determinations with radioactive phosphorus. Brit. Heart J., 7, 81, 1945.

(With C. Crafoord.) Congenital coarctation of the aorta and its surgical treatment. J. thorac. Surg., 14, 347, 1945.

Heart disease and pregnancy. Cardiologia, 11, 151, 1946/47.

(With B. Bernandt.) The relation between circulation time and the amount of the residual blood in the heart. Amer. Heart J., 32, 411, 1946.

The effect of adrenalin injected intravenously on the volume of circulating erythrocytes. Acta cardiol., 3/4, 225, 1946.

The circulatory blood volume of some organs. Amer. Heart J., 34, 174, 1947.

(With S. Hedlund.) Weight of the red blood corpuscles in heart failure determined with labelled erythrocytes during and after decompensation. Amer. Heart J., 33, 770, 1947.

(With S. Hedlund.) Variations in the quantity of red blood corpuscles in case of heart failure. Acta med. scand., 1948, Suppl. CCVI.

(With Hjordus Celander.) Determinations of the blood volume in the heart and lungs and the cardiac output through the injection of radiophosphorus. Circulation, 1, 76, 1950.

(With G. C. Sutton, A. Kappert, A. Reale, and C.-H. Skoglund.) Studies on 1-nor-epinephrine: relation of dosage to pressor and bradycardia effect. J. Lab. clin. Med., 36, 460, 1950.

Studies of the changes in the amount of the residual blood of the heart in man. Cardiologia, 17, 251, 1950.

(With G. de Hevesy.) Application of $\mathrm{K}^{42}$ labelled red corpuscles in blood volume measurements. Acta physiol. scand., 24, 285, 1951.

Oxygen debt in valvular stenosis before and after an operation. Hospital (Rio de Janeiro), 43, 559, 1953.

Willem Einthoven. Address given at Einthoven Commemoration Festival, Leyden 1953. Cardiologia, 24, 311, 1954.

(With H. Blomer, Hardin Jones, S. Hedlund, and C.-G. Rylander.) Further studies on the cerebral blood flow estimated with "Thorium B." Brit. Heart J., 18, 385, 1956.

The clinical applicability of roentgenological heart volume determination with special reference to the residual blood.

Acta cardiol., 12, 588, 1957.

(With S. Hedlund.) Blood flow and pool in heart, lungs and brain.

Circulation. Proceedings of the Harvey tercentenary Congress. Blackwell Scient. publications. Oxford 1958.

Estimation of cerebral blood flow and cerebral blood pool by the aid of labelled erythrocytes. Cerebral vascular diseases. Transactions of the second conference held under the auspices of the Amer. Heart Ass., Princetown 1957. Grune and Stratton, New York 1958.

(With B. P. Silfverskiold, S. Lofstedt, O. Regnstrom and S. Hedlund.) Studies on cerebral blood flow in man using radioactive-labelled erythrocytes. Brain, 83, (11) 293, 1960. man.

(With S. Hedlund and O. Regnstrom.) Studies of the cerebral circulation with labelled erythrocytes in healthy

Circulation Res., 9, 664, 1961. 